\title{
Research on noise level of wood processing machine groups
}

\author{
Hasan SERIN, Yunus SAHIN*, Semih DEMIR \\ Kahramanmaraş Sütçü İmam University, Faculty of Forestry, Kahramanmaras, TURKEY \\ *Corresponding author: ysahin@ksu.edu.tr
}

Received Date: 10.05.2017

Accepted Date: 27.07.2017

\section{Abstract}

Aim of study: Machines are commonly used at production and everywhere in daily life. Every machine which works during the production and blank time causes noise pollution. In view of occupational health and safety rules don't apply enough at workplace or small enterprises, these machines will have more negative effect on workers.

Area of study: This study has been performed at workplace and small forest products enterprises in Kahramanmaras.

Material and Methods: Average noise levels of wood processing machines at these enterprises have been determined with group. The noise levels of commonly used 22 number machine types have been determined at 56 enterprises in Kahramanmaras. While $48 \%$ of the measured machines were used for furniture, $52 \%$ of them was used for furniture and door production.

Main results: According to classification of wood processing machine it was determined that the

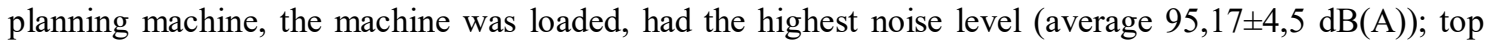

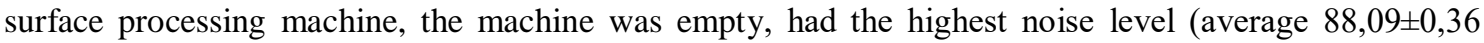
$\mathrm{dB}(\mathrm{A}))$.

Research highlights: Many of wood processing machines has critical noise levels so this situation can be dangerous for the workers. Enterprise's sustainability and productivity always fall down because of this work athmosphere. For occupational safety and health, the managers, and workers must follow the rules.

Keywords: Wood Processing Machines, Noise, Furniture, Kahramanmaras

\section{Ahşap işleme makine gruplarının gürültü düzeyinin araştırılması}

\section{Özet}

Çalışmanın amacı: Günlük hayatın her yerinde ve üretimde makineler yaygın olarak kullanılmaktadır. Üretimde ve boş durumda çalışan her makine ortamda gürültü kirliliğine sebep olmaktadırlar. Atölye veya küçük ölçekli işletmelerde iş sağllğı ve güvenliği kurallarının yeterince uygulanmadığı göz önüne alındığında bu makinelerin çalışanlar üzerinde olumsuz etkisi daha fazla olacaktır.

Çalışma alanı: Bu çalışma, Kahramanmaraş il merkezinde faaliyet gösteren atölye ve küçük ölçekli orman ürünleri işletmelerinde yürütülmüștür.

Materyal ve Yöntem: Bu işletmelerde yaygın olarak kullanılan ahşap işleme makineleri yaptıkları işlemlere göre gruplandırılarak ortalama gürültü düzeyleri belirlenmiştir. Kahramanmaraş ahşap malzeme işleyen 56 tesiste, yaygın olarak kullanılan 22 adet makine çeşidinin gürültü düzeyleri belirlenmiştir. Ölçüm yapılan makinelerin \%48'i mobilya üretiminde kullanılır iken \%52'si hem mobilya hem de kapı üretiminde kullanılmaktadır.

Sonuçlar:Ağaç işleme makine sınıflandırılmasına göre makinenin dolu durumda çalışır iken en yüksek gürültü düzeyi rendeleme makinelerinde ortalama $95,17 \pm 4,5 \mathrm{~dB}(\mathrm{~A})$, makineler boş durumda çalı̧ır iken üst yüzey işleme makinelerinde ortalama $88,09 \pm 0,36 \mathrm{~dB}(\mathrm{~A})$ olarak belirlenmiştir.

Araştırma vurguları: Bir çok ahşap işleme makinelerinin gürültü seviyeli kritik durumda olduğu için bu durum iş̧iler için tehlike arz etmektedir. $\mathrm{Bu}$ çalışma atmosferinden dolayı işletmenin sürüdürülebilirliği ve verimliliği düşmektedir. İş güvenliği ve sağllğı açısından yöneticiler ve işçilerin kurallara uymaları gerekmektedir.

Anahtar Kelimeler: Ahşap İşleme Makineleri, Gürültü, Mobilya 


\section{Introduction}

At the present time, the people are exposed to noise at all kinds of hard work such as construction works, stone and marble quarries, road works, and heavy equipment (Yalçınkaya et all. 2007). In recent years; legal documents as regulation, notification, rule and so on, which determine the top limits of noise levels at heavy equipment, have been determined with occupational health and environmental consciousness to prevent noise pollution.

The noise is unpleasant sounds and affects negatively on the people. The noise is unpleasant and undesirable mechanical vibrations that be formed with pressure changes in solid, liquid, and gaseous state. The changes in the air pressure reach as waves to sense organs and after that it is heard as sound. A vibration as characteristic is stated with its frequency and volume (Akan, 2002). Particularly, the noise level in large cities exceeds measurements which determine from World Health Organization (WHO). At the top of the results, that increase city noise, is intense traffic, honk, and the noise from industry areas (Aydin and Ateş, 1997). In addition to these, there is a continuous exposure to the noise at some work fields.

There are 2 different classifications from the noise: the frequency distribution and time-varying sound level. According to the frequency distribution; the noise goes into division as broadband noise and narrowband noise (Esen, 2010). On the other hand, in reference to time-varying sound level; the noise goes into division as stable and unstable (Ertürk, 2001; Anonymous, 2011).

There are some negative influences such as temporary or permanent hearing disorders, blood pressure increase, speeding at respiration, change at heart beatings, sudden reflex, some behavior disorders, extreme irritation and stress, concentration disorder, slowing the movements because of the noise but it depends on the time of noise exposure and it's volume (Güller and Çobanoğlu, 1994; Anonymous, 2012). In other words, the noise is an important factor which causes communication problem, unrest, damage on nervous system, decrease in working performance and hearing problems (Andrews, 1982; Feldman and Grimes, 1985). With these negative influences, it is possible that the various diseases or health problems originating from the noise occur depends on the time of noise exposure (Dalgıç, 1992).

After the results of researches, it is clearly that the noise affects differently from person to person. Interrupted and sudden noise may cause the heart beating increase, the blood pressure increase, sleeping disorders, losing attention. The sudden noise causes the heart beating increase, pupil constriction, quick temper, and anger (Güner, 2000).

Table 1. The decibel degrees of some noise types and it's psychological effects (Anonymous, 2006)

\begin{tabular}{|c|c|c|}
\hline Noise Type & $\mathrm{dB}(\mathrm{A})$ & Psychological effect \\
\hline Space rocket & 170 & \multirow{3}{*}{ Earache, nerve cells disorder } \\
\hline Siren & 150 & \\
\hline Ear endurance limit & 140 & \\
\hline Machine drill & 120 & \multirow{3}{*}{ Nervous and psychological disorders (3. Step) } \\
\hline Motorbike & 110 & \\
\hline Cabaret music & 100 & \\
\hline Subway noise & 90 & \multirow{5}{*}{ Psychological signs (2. Step) } \\
\hline Danger zone & 85 & \\
\hline Turning lathe & 85 & \\
\hline Alarm clock & 80 & \\
\hline Telephone bell & 70 & \\
\hline Human voice & 60 & \multirow{2}{*}{ Psychological signs (1. Step) } \\
\hline Sleep noise & 30 & \\
\hline
\end{tabular}


As shown at Table 1 , the noise has 4 influences in terms of psychological. While subway noise, alarm clock, and human voice are first and second step psychological signs, motorbike and cabaret music cause third step nervous and psychological disorders.

Relaxation time at work life may be two times of the maximum working time. For this reason, temporary hearing losses on workers increase in time and ultimately they turn into permanent hearing losses. The hearing losses consisted over $90 \mathrm{~dB}(\mathrm{~A})$ are permanent and they never get better. Researches show that the influences of noise (till $80 \mathrm{~dB}(\mathrm{~A})$ level) on human health can be prevented. For this purpose in the workplace conditions, it has been determined that the highest noise level is $80 \mathrm{~dB}(\mathrm{~A})$ during the 8 hourly working hours. It is hard to protect workers health in a place where has over the $90 \mathrm{~dB}(\mathrm{~A})$ noise level even so the sound is liked (Haksal, 1997).

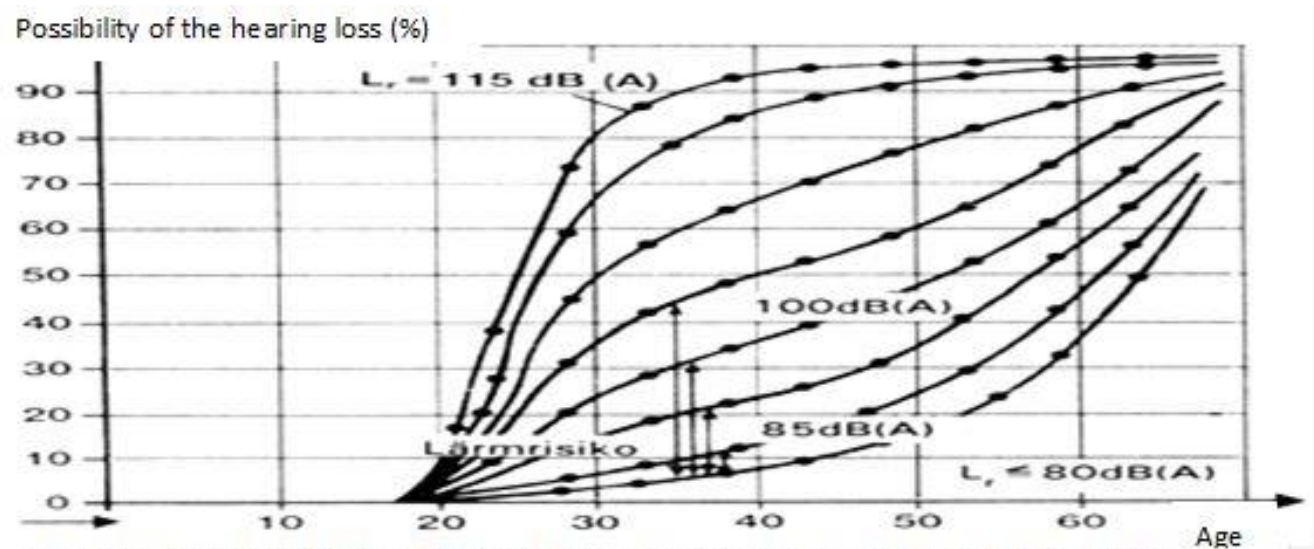

Figure 1. The possibility of hearing loss at noisy environment (Babalik, 2003)

The noise level as shown at Figure 1 gives the hearing loss possibility depends on working age and working hours. It is seen that a worker who is 20 years old has $50 \%$ and $65 \%$ the possibility of hearin ${ }^{\circ}$ loss respectively in case of working 30 and 40 years at $100 \mathrm{~dB}(\mathrm{~A})$ noise level.

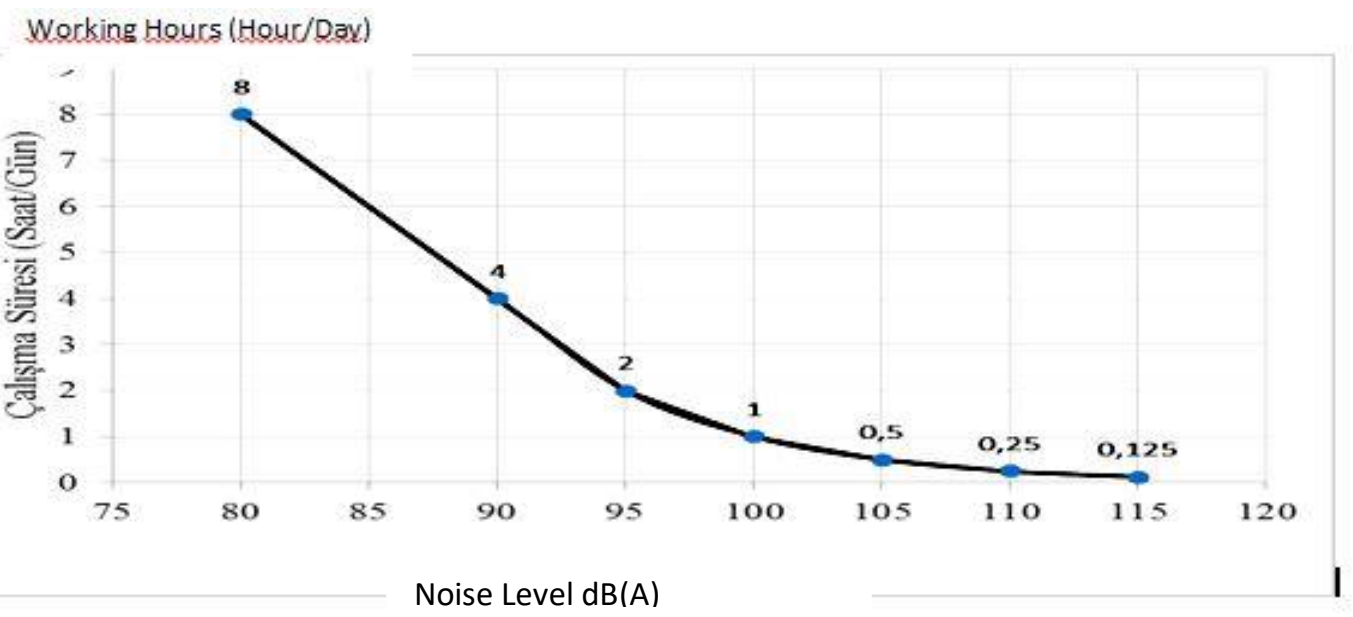

Figure 2. Noise levels and daily maximum working hours (OSHA, 1983).

As shown that at Figure 2, working hours have to be arranged according to the noise levels for the workers don't get the temporary and permanent hearing losses when the noise level increasing at working field. For instance; while a worker should be worked one hour maximum at $100 \mathrm{~dB}(\mathrm{~A})$ noise level, 
the worker can do two hours maximum at 95 $\mathrm{dB}(\mathrm{A})$ noise level.

\section{Wood processing machines}

The machines, which they are used for cutting, drilling, planning, profile, top- surface process and changing shape of wooden material, are called as wood processing machines. İlhan et al (1990) classified furniture industry machines as given the Table 2 with 10 groups.

Table 2. The Wood Processing Machines Types (Illhan et al., 1990)

\begin{tabular}{|c|c|c|}
\hline & a) Circular saw & b) Band saw \\
\hline $\begin{array}{l}\text { 1. Timber and board } \\
\text { cutting } \\
\text { dimensioning } \\
\text { machines }\end{array}$ & $\begin{array}{l}\text { - Pendulum length cutting } \\
\text { machine } \\
\text { - Length cutting machine by } \\
\text { bottom saw } \\
\text { - Radial length cutting machine } \\
\text { - Two-sided length cutting } \\
\text { machine } \\
\text { - Length cutting and multiple } \\
\text { perforation machine } \\
\text { - Circular saw machine } \\
\text { - Multiple circular saw machine } \\
\text { - Board cutting machine }\end{array}$ & $\begin{array}{l}\text { - Band saw machine } \\
\text { - Jigsaw machine }\end{array}$ \\
\hline 2. Planing machines & $\begin{array}{l}\text { - Planer } \\
\text { - Thickness machine }\end{array}$ & - Thickness and multiple slicing machine \\
\hline $\begin{array}{l}\text { 3. Profile and } \\
\text { shaping machines }\end{array}$ & $\begin{array}{l}\text { - Vertical milling machine } \\
\text { - Horizontal milling machine } \\
\text { - Quadripartite trimming } \\
\text { machine }\end{array}$ & $\begin{array}{l}\text { - Template and copy shaping machines } \\
\text { - Two-sided trimming machine }\end{array}$ \\
\hline $\begin{array}{l}\text { 4. Corner joint } \\
\text { machines }\end{array}$ & $\begin{array}{l}\text { - Automatic routing machine } \\
\text { - Finger joint machine } \\
\text { - Screwing machine }\end{array}$ & $\begin{array}{l}\text { - Routing and one-sided trimming machine } \\
\text { - Cross insertion machines }\end{array}$ \\
\hline 5. Boring machines & $\begin{array}{l}\text { - Horizontal boring machine } \\
\text { - Vertical boring machine } \\
\text { - Multiple vertical boring } \\
\text { machine } \\
\text { - Oscillation vertical boring } \\
\text { machine } \\
\text { - Chained angular boring } \\
\text { machine }\end{array}$ & $\begin{array}{l}\text { - Automatic multiple horizontal and vertical } \\
\text { boring machines } \\
\text { - Automatic knot patch machine } \\
\text { - Horizontal length boring machine }\end{array}$ \\
\hline $\begin{array}{l}\text { 6. Lining and } \\
\text { pressing machines }\end{array}$ & $\begin{array}{l}\text { - Lining preparation machines } \\
\text { - Lining cutting machine } \\
\text { - Lining adding machine } \\
\text { - Flat lining presses } \\
\text { - Montage presses }\end{array}$ & $\begin{array}{l}\text { - Glue preparation and spreading machines } \\
\text { - Frame press } \\
\text { - Box press } \\
\text { - Twisting presses }\end{array}$ \\
\hline $\begin{array}{l}\text { 7. Edging strip and } \\
\text { lining machines }\end{array}$ & $\begin{array}{l}\text { Edging strip machines } \\
\text { - One-side } \\
\text { - Two-sides } \\
\text { Edge lining machines } \\
\text { - One-side } \\
\text { - Two-sides }\end{array}$ & $\begin{array}{l}\text { Folio lining machine } \\
\text { - One-side } \\
\text { - Two-sides } \\
\text { - Quadripartite }\end{array}$ \\
\hline
\end{tabular}


Table 2. (continued)

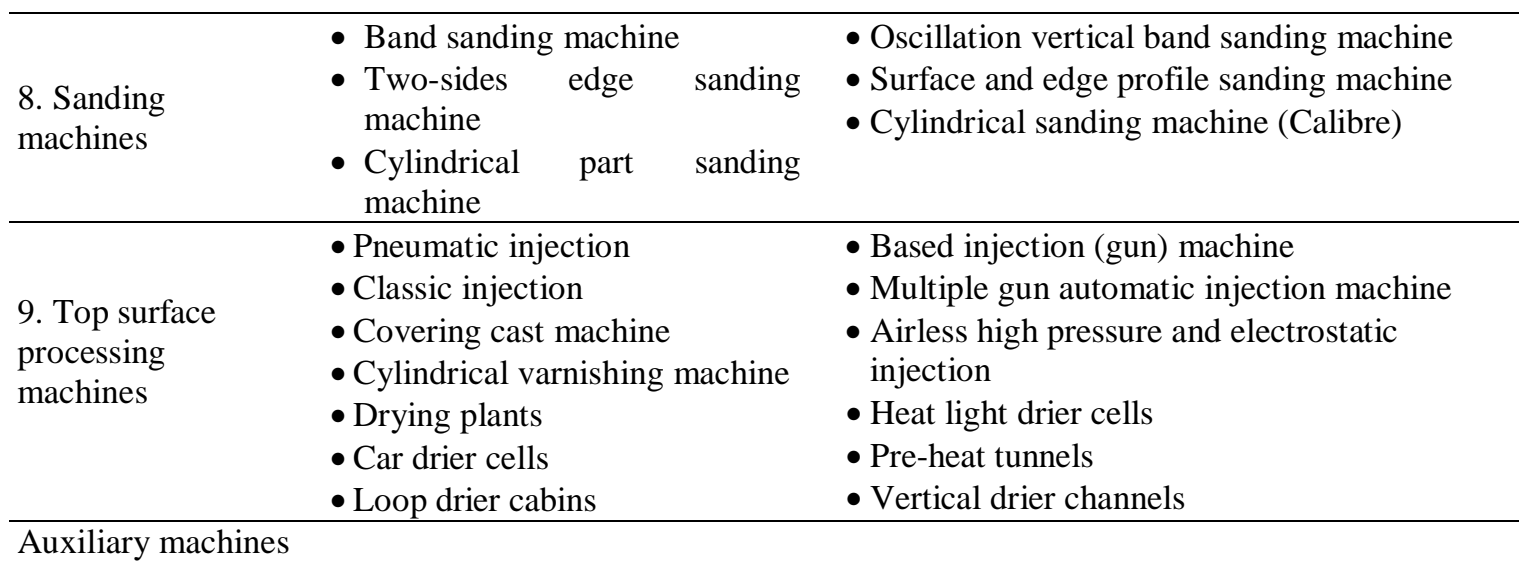

As given at Table 2; the furthest machines are in two groups which are top surface processing machines and timber-board cutting dimensioning machines.

\section{Material and Method}

This research has been done at furniture and door enterprises in Kahramanmaras city. There are not big enterprises which they produce furniture and door in this city. For this reason, this research has been done at small scale and studio type enterprises. The measurements were made with 3 minutes at 3 different points (material input to machine, material output and the place where the worker be) according to machines were loading and not. The measurements were saved every 5 seconds at 3 minutes and 30 items data occurred from all machines. From done literature review; while the measurements were made at least $15 \mathrm{~min}$ periods at unstable noise environment such as traffic (Atmaca and Peker, 1999), the measurements were mostly made $3 \mathrm{~min}$ periods at stable noise environment (Esen, 2010; Serin, 2012). DELTAOHM HD 2010 aawas used for noise measurements (Figure $3)$.

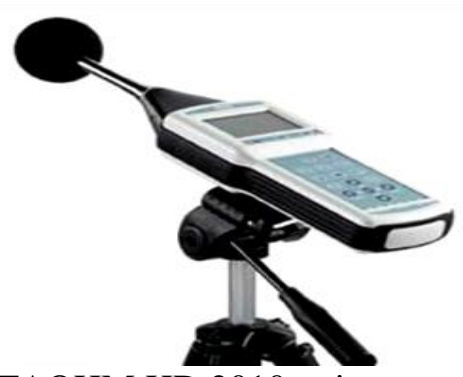

Figure 3. DELTAOHM HD 2010 noise measurement device

Device's batteries were checked, it was calibrated, the atmospheric features of environment were checked at working range of device and a plan of measurement place was made to make accurate the noise measurements. The measurement points, reflecting and absorber surfaces on the environment were marked over the plan. It was chosen accurate settings according to device's features and type of the noise (Serin at al., 2013).
Measured machines classified in reference to cutting theory on wood process and types of furniture industry machines (Table 2). As shown Table 2, timber and board cutting dimensioning machines are circular saw, band saw, drawer, miter saw, length cutting, dimensioning, slicing, double miter saw; planing machines are planing, thickness machine; profile and shaping machines are milling cutter, planing, and CNC (Computer Numerical Machine); boring machines are 
perforating, driller, and lock-out machine; lining and pressing machines are jumbo machine, frame press; sanding machines are band sanding machine, and vibrant sanding machines; top surface processing machines are slicing machine, and drying plants; auxiliary machines are dust absorber machines, compressor, knife sharpener machine.

The measurement data from the research was determined by basic statistics on SPSS program.

\section{Findings and Discussion}

Table 3. The noise level in reference to classification of wood processing machine when the machine without loading

\begin{tabular}{lccccc}
\hline \multicolumn{1}{c}{ Machine classification } & $\mathrm{N}$ & $\begin{array}{c}\text { Average } \\
\mathrm{dB}(\mathrm{A})\end{array}$ & $\begin{array}{c}\text { Standard } \\
\text { deviation }\end{array}$ & $\begin{array}{c}\text { Min. } \\
\mathrm{dB}(\mathrm{A})\end{array}$ & $\begin{array}{c}\text { Max. } \\
\mathrm{dB}(\mathrm{A})\end{array}$ \\
\hline Timber and board cutting dimensioning machines & 990 & 84,17 & 7,34 & 69,10 & 104,40 \\
\hline Planing machines & 360 & 85,28 & 4,48 & 76,60 & 96,30 \\
\hline Profile and shaping machines & 450 & 78,98 & 5,08 & 70,20 & 88,50 \\
\hline Boring machines & 330 & 79,36 & 5,48 & 70,90 & 93,30 \\
\hline Lining and pressing machines & 180 & 76,17 & 3,84 & 70,90 & 83,90 \\
\hline Sanding machines & 240 & 79,54 & 5,41 & 73,60 & 89,90 \\
\hline Top surface processing machines & 90 & 88,09 & 0,36 & 87,00 & 88,50 \\
\hline Auxiliary machines & 90 & 83,66 & 5,53 & 77,60 & 95,40 \\
\hline
\end{tabular}

As given at Table 3, the average noise level didn't mostly exceed the danger limit $(85 \mathrm{~dB}(\mathrm{~A}))$ when the machines were running without loading. On the other hand, planing and top surface process machine groups exceeded too little this limit. The maximum measurement $(96,3 \mathrm{~dB}(\mathrm{~A}))$ was saved at planing machines. It was determined that saved minimum measurements are acceptable noise levels in top surface processing machine groups.

The average noise level exceeded the danger limit $(85 \mathrm{~dB}(\mathrm{~A}))$ when the all
In this research, the noise levels of 22 number machine types were determined at 56 number enterprises where they produce furniture and door in Kahramanmaras city in reference to classification of wood processing machine. Measured machines were combined as 8 ranks according to the classification. 2730 number measurement data (average noise levels, standard deviation values, min-max noise values) of the machine without loading were given at Table 3 in reference to classification of wood processing machine.

Table 4. The noise level in reference to classification of wood processing machine when the machine with loading

\begin{tabular}{lccccc}
\hline \multicolumn{1}{c}{ Machine classification } & $\mathrm{N}$ & $\begin{array}{c}\text { Average } \\
\mathrm{dB}(\mathrm{A})\end{array}$ & $\begin{array}{c}\text { Standard } \\
\text { deviation }\end{array}$ & $\begin{array}{c}\text { Min. } \\
\mathrm{dB}(\mathrm{A})\end{array}$ & $\begin{array}{c}\text { Max. } \\
\mathrm{dB}(\mathrm{A})\end{array}$ \\
\hline Timber and board cutting dimensioning machines & 990 & 90,61 & 6,32 & 77,50 & 107,70 \\
\hline Planing machines & 360 & 95,17 & 4,50 & 85,40 & 107,70 \\
\hline Profile and shaping machines & 450 & 88,85 & 4,35 & 78,50 & 97,80 \\
\hline Boring machines & 330 & 93,79 & 8,51 & 79,30 & 106,50 \\
\hline Lining and pressing machines & 180 & 81,18 & 2,89 & 75,90 & 86,60 \\
\hline Sanding machines & 240 & 85,12 & 5,52 & 74,00 & 90,90 \\
\hline Top surface processing machines & 90 & 91,66 & 0,69 & 90,00 & 92,30 \\
\hline Auxiliary machines & 90 & 91,79 & 1,91 & 89,80 & 97,30 \\
\hline
\end{tabular}


The average noise levels were shown at Figure 4 while the machine was running without loading. The maximum value at planing machines was measured as approximately $85 \mathrm{~dB}(\mathrm{~A})$ while the machines without loading. The boring machine group had the minimum value as $73 \mathrm{~dB}(\mathrm{~A})$ also the auxiliary machines had the maximum noise level as $85 \mathrm{~dB}(\mathrm{~A})$ when the machines running without loading. In addition, it was seen that the least division was between minimum and maximum values at auxiliary machines.

Planing, boring, auxiliary and top surface machine groups, which exceed $90 \mathrm{~dB}(\mathrm{~A})$ noise level, should be running maximum 4 hours according to OSHA (1983) while the machines are running with loading. The working hours of workers should be determined in reference to Figure 3 for preventing temporary and permanent hearing losses.

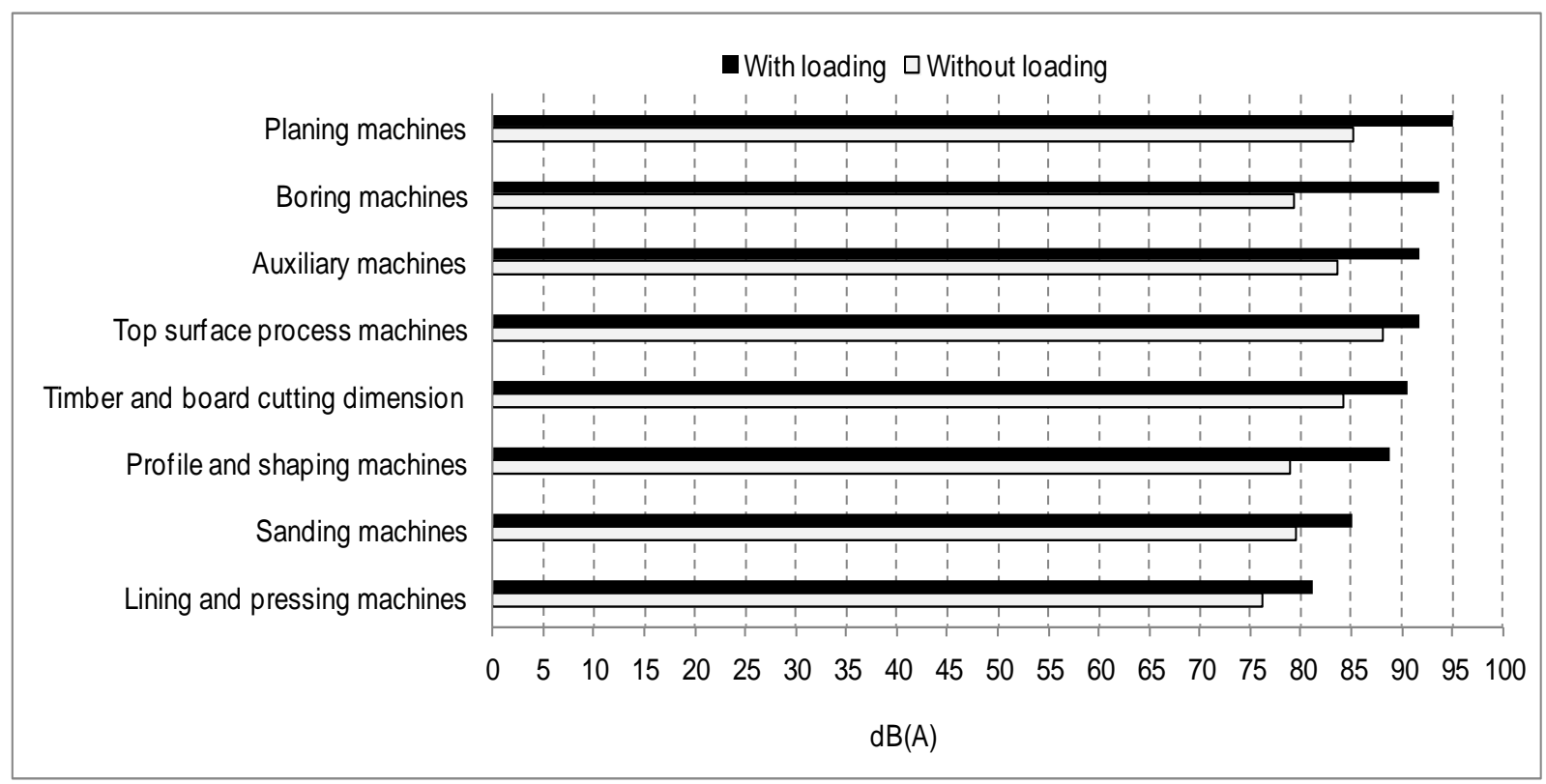

Figure 4 . The average noise level on wood processing machine groups

\section{Results}

As a result it was seen that the noise levels of machine groups, which produce furniture, have influences to human health. The worker should keep away environment, that is a noisy place over than $90 \mathrm{~dB}(\mathrm{~A})$, 1000 minutes for preventing temporary hearing loss $18-20 \mathrm{~dB}(\mathrm{~A})$ on the worker who works 100 minutes at this environment (Sabuncu, 1998).

As shown at Figure 4, it should be taken precautions such as engineering precautions on the machines, that exceed $85 \mathrm{~dB}$ (A) limit noise level (planing machines, timber and board cutting dimension machines, boring machines, profile and shaping machines, top surface processing machines and auxiliary machines), and also some precautions about lessen the noise influence on the workers. In addition, it should be given some knowledge to the workers about potential risks from the noise. Enough relaxing-working ranges should be arranged. The workers should go through physical tests and their health records should be made regularly.

\section{References}

Akan, Z. (2002). Van Hava Alanında Oluşan Gürültü Kirliliğinin Çalıșanlar Üzerindeki Etkileri. Yüzüncü y1l üniversitesi, Yüksek Lisans Tezi. Van, 86.

Andrews, G.J.A.B. (1982). Ergonomics Fundamentalsof seniorpupils, Napier College, Collington Road; Edinburgh.

Anonim, (2012). Gürültünün Etkileri, T.C Milli Eğitim Bakanlığı, Aile ve Tüketici Hizmetleri, Ankara, 29.

Anonim, (2006). Gürültü ve Gürültü Kirliliği Orman ve Su İşleri Bakanlığı. Ankara.

Gürültü düzeyleri çalışması, 75. 
Anonim, (2011). Çevresel Gürültü Ölçüm ve Değerlendirme Kilavuzu, Çevre ve Orman Bakanlığı Çevre Yönetimi Genel Müdürlüğü Ankara.

Atmaca, E. ve Peker, İ. (1999). Sivas'ta Trafik Gürültüsü, Ekoloji Çevre Dergisi, Cilt 8, Sayı 30, 3-8.

Aydın, M. E., Ateş, N. (1997). Konya'da Trafik Gürültüsü ve Bazı Öneriler,Journal of Engineering Sciences, 3 (3) 447-456.

Babalık, F. (2003). İş Yerinde Gürültü ve Sağırlık Olasılığ 1 . Mühendis ve Makine Dergisi,

http://www.mmo.org.tr/resimler/dosya_ek ler/b04d152845ec0a3_ek.pdf?dergi $=50$ (Erişim Tarihi:24.06.2016)

Dalgıç, N. (1992). Gürültü ve Sağlık, Sağlık ve Sosyal Yardim Vakfi Dergisi, 3:5-7.

Esen, M. (2010). Üretim Sahasında Gürültü ve Gürültü Kontrol Uygulaması. Yıldız Teknik Üniversitesi Fen Bilimleri Enstitüsü Yüksek Lisans Tezi. İstanbul. 107.

Ertürk, B. (2001). Hidrolik Gürültü ve Azaltma Yöntemleri, II. Ulusal Hidrolik Pnömatik Kongresi ve Sergisi, 8-11 Kasim 2001, İzmir, 213-236.

Feldman, A.S., Grimes, C.T. (1985). Hearing Conservations in Industry, Williams \&Wilkings; London.

Güller, Ç., Çobanoğlu, Z. (1994). Gürültü, Sağlık Bakanlığı Çevre Sağlığı Temel Kaynak Dizisi 19, Ankara, 43.

Güner, C. (2000). Gürültünün Sağlık Üzerine Etkileri, Sürekli Tıp Eğitimi Dergisi, (9)7:251-253.

Haksal, V. (1997). Gürültü ile Oluşan İşitme Kayıpları ve Korunma Yolları. Mühendis ve Makine TMMOB Makine Mühendisleri Odası Aylık Yayını, (451): 28-29.

İlhan, R., Burdurlu, E., Baykan, İ. (1990). Ağaç İşlerinde Kesme Teorisi ve Mobilya Endüstri Makinaları, Bizim Büro Basımevi, 361.

OSHA, (1983). Occupational Noise Exposure: Hearing Conservation Amendmend. Federal Register, Occupational Safety and Health Administration (OSHA) 48, 9738-9783.

Sabuncu, H. (1998). Fiziksel Etkilere Bağl1 Meslek Hastalıkları. İşyeri Hekimliği
Ders Notları, Türk Tabipler Birliği Yayın1. Ankara s.207-226.

Serin, H. (2012). Analysis of noise levels in corrugated board factories, International Journal of Physical Sciences Vol. 7(11), pp. $1857-1861$.

Serin H., Şahin, Y., Durgun, M. (2013). Küçük Ölçekli Mobilya İşletmelerinde Gürültü Analizi, Ormancılık Dergisi 9 (2) 1-8.

Yalçınkaya, K. A., Arıkoğlu, T., ve Çalışkan, M. (2007). İş Makinalarında Gürültü Kontrolü, Mühendis ve Makine Dergisi, 48 (571) 9-13. 